\title{
Diagnostic microbiology in veterinary dermatology: present and future
}

Guardabassi, Luca; Damborg, Peter; Stamm, Ivonne; Kopp, Peter A; Broens, Els M.; Toutain, Pierre-Louis

Published in:

Veterinary Dermatology

DOI:

$10.1111 /$ vde. 12414

Publication date:

2017

Document version

Publisher's PDF, also known as Version of record

Document license:

CC BY-NC

Citation for published version (APA):

Guardabassi, L., Damborg, P., Stamm, I., Kopp, P. A., Broens, E. M., \& Toutain, P-L. (2017). Diagnostic microbiology in veterinary dermatology: present and future. Veterinary Dermatology, 28(1), 146-e30. https://doi.org/10.1111/vde.12414 


\title{
Diagnostic microbiology in veterinary dermatology: present and future
}

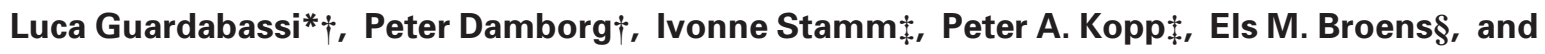 \\ Pierre-Louis Toutainף, the ESCMID Study Group for Veterinary Microbiology
}

\begin{abstract}
*Department of Biomedical Sciences, Ross University School of Veterinary Medicine, PO Box 334, Basseterre, St Kitts and Nevis, West Indies $\dagger$ Department of Veterinary Disease Biology, Faculty of Health and Medical Sciences, University of Copenhagen, Stigbøjlen 4, 1870 Frederiksberg, Denmark

†IDEXX Vet.Med.Labor, Moerikestrasse 28/3, D-71636 Ludwigsburg, Germany

§Department of Infectious Diseases and Immunology, Faculty of Veterinary Medicine, Utrecht University, Yalelaan 1, 3584 CL Utrecht, The Netherlands

qUMR 1331 Toxalim INRA/INP, Ecole Nationale Vétérinaire de Toulouse, 23 Chemin des Capelles, BP 87614, 31076, Toulouse Cedex 3, France

Correspondence: Luca Guardabassi, Department of Biomedical Sciences, Ross University School of Veterinary Medicine, PO Box 334 , Basseterre, St Kitts and Nevis, West Indies. E-mail: Iguardabassi@rossvet.edu.kn
\end{abstract}

\begin{abstract}
Background - The microbiology laboratory can be perceived as a service provider rather than an integral part of the healthcare team.

Objectives - The aim of this review is to discuss the current challenges of providing a state-of-the-art diagnostic veterinary microbiology service including the identification (ID) and antimicrobial susceptibility testing (AST) of key pathogens in veterinary dermatology.
\end{abstract}

\begin{abstract}
Methods - The Study Group for Veterinary Microbiology (ESGVM) of the European Society of Clinical Microbiology and Infectious Diseases (ESCMID) identified scientific, technological, educational and regulatory issues impacting the predictive value of AST and the quality of the service offered by microbiology laboratories.
\end{abstract}

\begin{abstract}
Results - The advent of mass spectrometry has significantly reduced the time required for ID of key pathogens such as Staphylococcus pseudintermedius. However, the turnaround time for validated AST methods has remained unchanged for many years. Beyond scientific and technological constraints, AST methods are not harmonized and clinical breakpoints for some antimicrobial drugs are either missing or inadequate. Small laboratories, including in-clinic laboratories, are usually not adequately equipped to run up-to-date clinical microbiologic diagnostic tests.
\end{abstract}

Conclusions and clinical importance - ESGVM recommends the use of laboratories employing mass spectrometry for ID and broth micro-dilution for AST, and offering assistance by expert microbiologists on pre- and post-analytical issues. Setting general standards for veterinary clinical microbiology, promoting antimicrobial stewardship, and the development of new, validated and rapid diagnostic methods, especially for AST, are among the missions of ESGVM.

\section{Introduction}

In veterinary medicine, the microbiology laboratory is perceived as a service provider rather than an integral part of the healthcare team, resulting in limited interaction between microbiologists and clinicians. This differs from human medicine, where microbiologists interact with infectious disease specialists to provide advice on antimicrobial therapy, infection control, antimicrobial stewardship practices, antimicrobial resistance trends and compliance with antimicrobial guidelines. The use of

Accepted 13 November 2016

This article is based on a Supporting Review presentation at the 8th World Congress of Veterinary Dermatology held May 2016 in Bordeaux, France.

Sources of Funding: This study was self-funded. Conflicts of Interest: No conflicts of interest have been declared. diagnostic microbiology is comparatively lower than in human medicine, although differences exist between countries and veterinary practices. ${ }^{1}$ This difference is attributable to structural, economic and cultural factors that differentiate the veterinary healthcare system from the human counterpart. The limited utilization of microbiology tests in veterinary practice has negative consequences on the costs, with these being as much as three times higher than the costs of comparable tests in the human healthcare sector. Formal antimicrobial stewardship programmes, which traditionally involve microbiology laboratories in human hospitals, are rarely implemented by veterinary clinics. ${ }^{2}$ Antimicrobials are mainly used empirically and the use of antimicrobial susceptibility testing (AST) is generally limited to difficult cases with poor response to initial therapy. ${ }^{1}$ This trend is unfortunate given the current concerns regarding antimicrobial use and emergence of multidrug-resistant bacteria in animals, including companion animals. ${ }^{3}$ Use of culture and AST to guide antimicrobial choice is recommended

146 C 2017 The Authors. Veterinary Dermatology published by John Wiley \& Sons Ltd on behalf of the ESVD and ACVD, 28, $146-e 30$.

This is an open access article under the terms of the Creative Commons Attribution-NonCommercial License, which permits use, distribution and reproduction in any medium, provided the original work is properly cited and is not used for commercial purposes. 
by numerous guidelines on responsible antimicrobial use developed by governmental, animal health and veterinary organizations, including the European Commission, ${ }^{4}$ the World Organization of Animal Health (OIE) ${ }^{5}$ and the American Veterinary Medical Association (AVMA). ${ }^{6}$ As demonstrated in human medicine, implementation of antimicrobial stewardship at the clinic level has positive consequences on appropriate antimicrobial use, control of antimicrobial resistance and patient care. ${ }^{7}$

Quality and quality control are important in clinical microbiology. International standards $s^{8,9}$ and manuals ${ }^{10,11}$ for clinical microbiology are available but their use is, for the most part, voluntary, although some guidelines have been adopted by accrediting organizations as part of their accreditation requirements. Uniform guidelines for best practice are not widely available for veterinary clinical microbiological laboratories; in general, accredited laboratories have implemented the guidelines for human clinical microbiology laboratories. Furthermore, there is an increasing trend for veterinary clinics to perform inhouse microbiology. Despite the advantages of reduced turnaround time and costs, there are also disadvantages and risks associated with this practice. The microbiological expertise required to accurately perform and interpret the diagnostic tests, as well as to perform routine quality control and manage the biohazard risks, are lacking in most in-clinic and small diagnostic laboratories.

The aim of the Study Group of Veterinary Microbiology (ESGVM), established within the European Society for Clinical Microbiology and Infectious Diseases (ESCMID), is to promote state-of-the-art veterinary clinical microbiology. This review highlights some of the current challenges in veterinary microbiology and outlines the quality standards required with particular reference to veterinary dermatology.

\section{State-of-the-art methodologies}

\section{Microbe identification}

Classic culture-based methods have been the mainstay of clinical microbiology for the past century. Automated systems are being implemented, but to date most of these technologies rely on pure culture of the microorganism. Identification (ID) of the micro-organism is an important prerequisite before AST to distinguish between potentially pathogenic micro-organisms and possible contaminants from the commensal microbiota on nonsterile body sites. Microbial ID has traditionally been performed by testing biochemical properties of the micro-organism. A step forward was achieved with the development of standardized commercial test systems (e.g. API ${ }^{\circledR}$ or rap $\left(D^{T M}\right)$, which have gradually replaced the use of inhouse tube tests, enabling diagnostic laboratories to use a validated manual system without expensive hardware. The next step was to offer these tests in more or less automated versions to avoid subjective interpretation (e.g. VITEK ${ }^{\circledR}$ Systems, BD Phoenix ${ }^{\mathrm{TM}}$ Automated Systems, TREK Sensititre ${ }^{\circledR}$ Diagnostic Systems). The quality of these systems in veterinary microbiology is strongly dependent on the databases used. Species found commonly in human microbiology, such as Pseudomonas aeruginosa, are well represented within the databases of these ID systems and therefore reliably identified. However, some species of veterinary relevance, including Staphylococcus pseudintermedius and Staphylococcus felis, are very difficult to reliably identify and differentiate from closely related staphylococci. Additionally, as the biochemical activity of a strain depends on growth, microorganisms that do not grow in these systems cannot be identified (e.g. some members of Pasteurellaceae) and the ID may not be reliable for some micro-organisms (e.g. Malassezia) if the patient is under treatment with antimicrobials at the time of specimen collection.

New technologies have been introduced in recent years to overcome the disadvantages of biochemical ID. One technology that has gained increasing attention in veterinary microbiology is MALDI-TOF (matrix-assisted laser desorption/ionization-time of flight) mass spectrometry (MS) (Figure 1). This technique identifies any culturable bacteria within minutes and has low running costs. ${ }^{12,13}$ For most fungi a somewhat more complex sample preparation is necessary, but even dermatophytes can be identified with this method within $2 \mathrm{~h}$. Again, identification depends on database entries, but the ability to discriminate between different bacteria is generally very good for most species. In general, the available databases are much broader than any of the former biochemistry based databases, but still some veterinary specific entries are lacking. The databases are updated

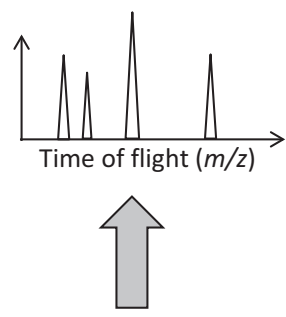

Generation of mass spectrum

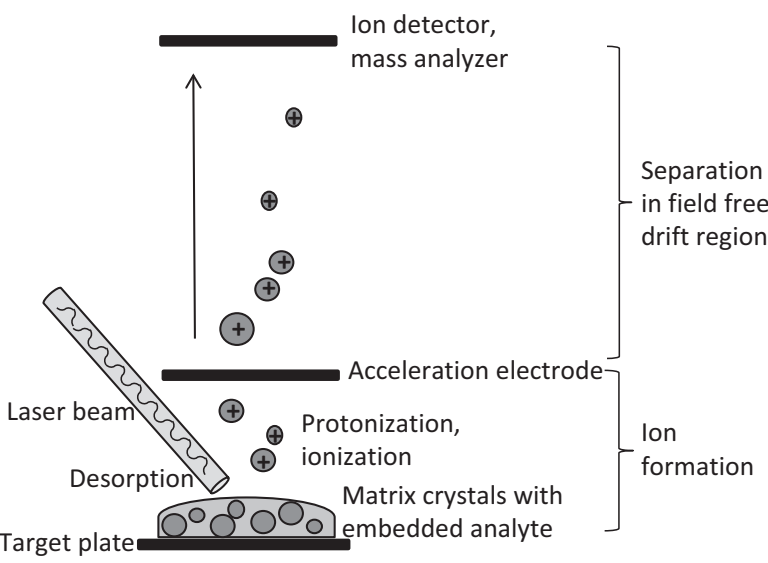

Figure 1. Principle of the MALDI-TOF (matrix-assisted laser desorption/ionization-time of flight) MS process. For most bacteria a simple direct smear preparation onto a target plate is covered by a matrix solution to enable the generation of ions by a laser. These ions, derived mainly from the highly abundant proteins of the micro-organism, are then accelerated and travel through a predefined distance in a vacuum tube (field free drift range). The time delay of their journey until the ions reach a detector is measured and displayed according to the mass of the ions as a characteristic pattern of the proteins (spectrum) detected in the micro-organism. Identification is then derived from comparison of the protein profile to database matches. 
regularly and each laboratory can add entries to the database. This approach has been shown to be successful for the Staphylococcus intermedius group (SIG), which is of special importance in the field of dermatology. ${ }^{14}$ Of course, a prerequisite for database expansions are strict protocols for quality control that must be followed to ensure highly reliable entries. In general, confirmation of the respective strains by sequencing before addition to the database is necessary. In human medicine, MALDITOF MS is used for direct ID of bacteria in blood cultures. ${ }^{15}$ Similar applications for direct ID in veterinary clinical specimens have not yet been developed. The main disadvantage of this technology is the high cost for purchasing and servicing the instrument, which makes it unaffordable by small diagnostic laboratories. However, the actual cost of the test is extremely low and alliance between laboratories may be used to make this technology accessible without every laboratory buying the instrument.

Another technology, DNA sequencing, is widely used as a research tool to investigate bacterial evolution and molecular epidemiology; at the time of writing this is not frequently employed in routine clinical microbiology. Recently, more advanced sequence-based techniques have become available. ${ }^{16}$ Isolated and purified microorganisms can be identified by Whole Genome Sequencing (WGS) over $24 \mathrm{~h}^{17}$ and publicly available web tools are available for multi-locus sequence typing (MLST) and ID of acquired antimicrobial resistance genes using raw WGS data. ${ }^{18,19}$ Direct sequencing of DNA extracted from clinical specimens enables bacteria ID in polymicrobial samples and reduces diagnostic times to $24 \mathrm{~h} .{ }^{20}$ DNA sequencing technologies are rapidly evolving and becoming more affordable, but widespread implementation in veterinary microbiology laboratories in the near future probably is limited to larger laboratories.

\section{Antimicrobial susceptibility testing}

Broth micro-dilution and disk diffusion are the most widely used methods for AST. Broth micro-dilution is the gold standard method for AST and the only method for which an internationally accepted ISO standard exists (ISO 20776-1, 2006). ${ }^{9}$ The principle of this method is simple. Broth suspensions containing the test strain are added to wells containing two-fold dilutions of antimicrobials. Upon incubation, the minimum inhibitory concentration $(\mathrm{MIC})$ is read for each antimicrobial as the lowest concentration inhibiting visible bacterial growth, and used for interpretation of susceptibility. The method can be highly automated and is generally performed using commercial panels with a fixed composition of antimicrobials. Disk diffusion, also known as the Kirby-Bauer method, is performed by streaking broth containing the test strain on an agar plate followed by applying antimicrobial-impregnated disks. Upon incubation, inhibited bacterial growth around each disc is measured as a zone diameter and used for interpretation of susceptibility. This method is cheaper and more flexible than broth micro-dilution, as the user can easily change the antimicrobials between tests. It is, however, less robust and reproducible, and semi-quantitative in nature as it only indicates whether the test strain is susceptible (S), intermediate (I) or resistant (R). Laboratories have to select the most appropriate antimicrobials for routine AST based on bacterial species, breakpoint availability, animal species, infection site and available guidelines. The major shortcoming of both methods is turnaround time (approximately $48 \mathrm{~h}$ ) from culture of the clinical specimen to reporting of the results. Both methods must be performed following quality standards (e.g. inoculum density and size, media, incubation conditions, etc.) that are set by two international committees; namely the European Committee on Antimicrobial Susceptibility Testing (EUCAST) and the Clinical and Laboratory Standards Institute (CLSI), and various national committees. To date, only CLSI provides clinical breakpoints and interpretive criteria for veterinary pathogens. ${ }^{21}$ A veterinary subcommittee of EUCAST (VetCAST) recently has been established with the purpose of harmonizing AST in Europe as well as on a global scale (http://www.eucast.org/organization/subcommittees/ve tcast/).

Alternative technologies are currently being evaluated to reduce the turnaround time of AST. Real-time PCR assays have been developed for rapid detection of resistant bacteria of high clinical relevance such as meticillinresistant Staphylococcus aureus (MRSA) directly from specimens. ${ }^{22}$ MALDI-TOF MS can be employed for rapid detection of extended-spectrum beta-lactamase (ESBL)producing bacteria in blood cultures through quantification of $\beta$-lactam degradation products. ${ }^{23}$ Flow cytometry is a method used for detection of morphological and metabolic changes of cells, for example upon antimicrobial exposure. This method has been tested for rapid AST of various organisms, and one study demonstrated the potential for detecting ESBL in $3 \mathrm{~h}$ from pure bacterial cultures. $^{24}$

WGS is not yet as rapid as these two other methods but offers the advantage of enabling screening of all known resistance genes by a single analysis, and it requires little hands-on time. WGS provides information on the presence of resistance genes, allowing prediction of antimicrobial susceptibility. High (99.7\%) accordance between pheno- and genotypic resistance was demonstrated between 200 bacterial isolates belonging to four different species, ${ }^{19}$ and the same predicted susceptibility profiles have been obtained using direct sequencing on clinical specimens and sequencing of single isolates. ${ }^{20}$ The disadvantage of WGS is that it fails to reveal as yet undescribed resistance genotypes, and the actual phenotype may not always be deduced from sequencing data. For example, detection of nonfunctional pseudogenes or repressed efflux systems may lead to false positive (R) results.

\section{Point-of-Care testing}

Point-of-Care (PoC) tests are diagnostic tests that can be performed with the patient, therefore reducing turnaround time. The tests are based on different technologies, predominantly immunochromatography, agglutination assays and real-time PCR. ${ }^{25} \mathrm{~A}$ rapid immunoassay for PoC detection of urinary tract infection in dogs (RapidBac ${ }^{\text {TM }}$ Vet; http://www.rapidbacvet.com/) has a high sensitivity (97.4\%) and specificity (98.8\%) for identification of clinical bacteriuria. ${ }^{26}$ A limited number of commercial PoC tests 
are available for on-site AST in veterinary clinics. A simple diagnostic system (Speed-Biogram ${ }^{\mathrm{TM}}$; https://www.bvt.fr/ en/home/diagnostic-solutions/pour-le-veterinaire-praticien/ infectious-diseases/main/gamme-speed/speed-biogram-1. html) has become available and can perform simultaneous ID and AST on cutaneous and ear specimens within 24-48 h. The main disadvantage is that the inoculum might be polymicrobial and cannot be standardized, leading to possible false resistance or false susceptibility reporting, which may also arise with disk diffusion testing.

Direct AST of clinical specimens (e.g. urine), without prior isolation of bacterial colonies, has the advantage of making results available earlier but this is controversial because of concerns regarding its accuracy. A human study demonstrated a 93\% agreement between direct and conventional AST. ${ }^{27}$ The highest percentage of discordance (13\%) was observed for $\beta$-lactam antimicrobial drugs such as amoxicillin clavulanate and cephalosporins. Similar results have been reported for another PoC test designed for direct ID and AST of uropathogens (Flexicult $^{\circledR}$ Vet; http://www.ssidiagnostica.dk/da/Produkter/ Substrater/Flexicult-Vet-URINKIT). ${ }^{28}$ In human medicine, direct AST is recommended only for critically ill patients and does not replace conventional AST, which is additionally performed to confirm the preliminary results obtained by direct AST ${ }^{26}$ Accordingly, ESGVM recommends that samples testing positive and strains testing resistant by PoC tests are sent to accredited laboratories for AST by validated methods. In some countries (e.g. France), PoC tests are not permitted for AST of critical antimicrobial drugs (e.g. fluoroquinolones and higher generation cephalosporins) due to test limitations. Conversely, PoC tests may be useful for rapid detection of negative samples and susceptible strains, avoiding the time and the cost of laboratory analysis.

\section{Current challenges in veterinary diagnostic microbiology}

\section{Specimen management}

Improper specimen management impacts on both the diagnosis and outcome of therapy. ${ }^{29}$ Microbiology laboratories should provide information to ensure the appropriate selection, collection, storage and transportation of clinical specimens. National and international guidelines provide detailed information on the best sample type, sampling technique and transport conditions for bacterial infections. For superficial bacterial folliculitis, pustular contents and papule biopsies are optimum. Swabs of crusts and epidermal collarettes result in a higher risk of contamination with commensal skin surface bacteria. ${ }^{30}$ For wound infections, the type of specimen and sampling technique depend on the wound type. ${ }^{30}$ In general, biopsy samples obtained after initial debridement and cleansing are the most useful for determining the microbial load and the presence of relevant pathogens. Fluid samples obtained by aseptic needle aspiration may be used for cavity wounds (e.g. pressure sores) and cutaneous abscesses. The value of wound swabs even after cleansing a wound prior to sampling is questionable. ${ }^{31}$ Visible contamination, however, should be removed before a sample is collected.

Usually a single lesion is sampled and relatively few colonies are used by the laboratory for both ID and AST. Recent studies have demonstrated, however, that multiple strains with distinct antimicrobial resistance profiles may occur in the same lesion or in different lesions from the same patient. ${ }^{32,33}$ Further evaluation to assess the magnitude and clinical significance of this phenomenon is indicated. In theory, the involvement of multiple strains from canine skin infections is plausible given the frequent carriage of multiple $S$. pseudintermedius strains in dogs. ${ }^{34}$ Primary isolation using commercial selective agar plates may be performed in addition to nonselective isolation on blood agar to facilitate detection of meticillin-resistant staphylococci occurring at low numbers in mixed cultures. Unless anaerobic bacteria are being investigated (e.g. deep wound infections), storage and transportation of dermatological specimens does not present any specific challenges, because the main pathogens involved (Table 1) can survive for several days in transport media. Nevertheless, sample pickup by courier and overnight transport offer the advantage of reducing the overall turnaround time.

\section{Pathogen identification}

Bacterial species relevant for common disease conditions in veterinary dermatology are listed in Table 1. Staphylococci are the most frequent bacterial pathogens associated with skin and soft tissue infections. Historically,

Table 1. Performance of biochemistry, including manual and automated methods, and MALDI-TOF MS for species identification of micro-organisms of recognized clinical relevance in veterinary dermatology

\begin{tabular}{lll}
\hline Micro-organism & Biochemistry & MALDI-TOF MS \\
\hline Staphylococcus pseudintermedius & Inadequate & Inadequate with standard database \\
Staphylococcus schleiferi & Inadequate & Good (no distinction between subspecies) \\
Staphylococcus aureus & Good & Excellent \\
Staphylococcus felis & Inadequate & Good \\
B-haemolytic streptococci & Good & Good at species level \\
& & Inadequate at subspecies level (excellent with extended database) \\
Pseudomonas aeruginosa & Good & Excellent \\
Proteus spp. & Good & Excellent \\
Dermatophytes & Good & Good (M. canis: excellent; Trichophyton spp.: genus level only) \\
Malassezia spp. & Inadequate & Good \\
Candida spp. & Inadequate & Good \\
\hline
\end{tabular}

MALDI-TOF (matrix-assisted laser desorption/ionization-time of flight) mass spectrometry (MS). 
animal pathogenic staphylococci have been associated with coagulase-positive staphylocci (CoPS), whereas CoNS generally have been regarded as bacteria with low pathogenic potential. Before the description of $S$. intermedius in 1976, ${ }^{35}$ all CoPS isolated from animals were (mis)identified as S. aureus. Subsequently, S. intermedius was differentiated into three distinct species: S. intermedius, S. delphini and S. pseudintermedius (referred to as the SIG group). ${ }^{36}$ The latter species is the normal commensal and opportunistic pathogen of the dog, even though infections also are reported in cats and less frequently in other hosts, including humans. ${ }^{37}$ Staphylococcus pseudintermedius cannot be easily distinguished from the other members of the SIG group by phenotypic methods and its speciation requires PCRbased tests or MALDI-TOF MS, provided that the database has been specifically refined for identification of this species (see above).

CoNS are commensal organisms with a relatively high rate of meticillin-resistance in companion animals. ${ }^{38}$ CoNS have been regarded as "contaminants" and either not reported or speciated except when isolated in pure culture from hospital-acquired infections associated with surgery or invasive procedures. The recognition of S. schleiferi ${ }^{39,40}$ as a canine pathogen underpins the importance of identifying CoNS species as the coagulase activity of this species and subspecies (subspp. schleiferi and coagulans) is variable. MALDI-TOF MS is superior to other methods for the identification of this group of staphylococci. ${ }^{41}$ ESGVM recommends that AST profiles for S. schleiferi and other CoNS should only reported when the organisms are isolated in pure culture from sterile sites or from intact primary skin lesions sampled under strict aseptic conditions.

Polymicrobial cultures are common for otitis and wound infections, and can occur from skin samples. In these cases, the relevance of the culture result and the selection of the isolate for AST need to be determined. The current recommendation for human wound infections is that growth of potential pathogens should be reported, preferably semi-quantitatively. ${ }^{30}$ AST should be performed when a pathogen is isolated in pure culture or in abundance with minimal involvement of other micro-organisms. Antimicrobial therapy should target the micro-organism with greatest pathogenic potential. Indiscriminate reporting of AST profiles for micro-organisms of minimal clinical relevance is discouraged to avoid unnecessary use of broad-spectrum antimicrobial drugs to cover the composite AST profile of multiple isolates.

\section{Lack or inadequacy of clinical breakpoints}

A clinical breakpoint (CBP) is the critical MIC (or the corresponding interpretive inhibition zone diameter for disk diffusion) selected by ad hoc international (e.g. CLSI or EUCAST) or national (e.g. US Food and Drug Administration) committees to categorize a bacterial strain as susceptible (S), intermediate (I) or resistant (R). CBPs are typically established on the basis of microbiological, pharmacokinetic (PK), pharmacodynamic (PD) and clinical outcome data. ${ }^{42}$ The purpose of CBPs is to assist clinicians to select appropriate drugs for therapy. In vitro AST does not, however, consider other factors that affect the outcome of antimicrobial therapy, such as host immune status, co-morbidities, strain virulence and compliance. By definition, a strain is reported susceptible to a drug when the standard dosage regimen is associated with a high likelihood of therapeutic success (approximately $90 \%$ according to human studies). The resistant category does not unequivocally predict treatment failure but a reduction of therapeutic success with a cure rate up to $60 \%$. This is referred to as the $90-60 \%$ rule in human medicine. ${ }^{43,44}$ The clinical predictive value of AST is further impacted in veterinary medicine by the lack, or inadequacy, of available breakpoints. For example, breakpoints are unavailable for several antibiotics suitable for the treatment of skin infections in cats (Table 2). In those cases a CBP from dogs would typically be used. For bacteria or infections without any veterinary CBP, a humanderived CBP may be employed. This is the case for sulphonamides/trimethoprim and antibiotics such as chloramphenicol or rifampicin used for treatment of MRSA and meticillin-resistant S. pseudintermedius (MRSP) infections (Table 2). Cefovecin is a veterinary drug for which no CBP exist, hence the in vivo efficacy of this drug is difficult to predict by AST. Clearly, the predictive value of AST can be severely impacted by the use of inadequate CBPs, because a human CBP reflects the dosage regimen and the $\mathrm{PK}$ of the drug in humans, and both dosage regimen and drug disposition exhibit large differences between animal species. Reliable CBPs require animal species-specific determinations and there is an urgent need for animal-specific CBPs.

CBPs are dosage regimen-dependent because they are set by PK/PD analysis according to a specific dosage. Thus, a CBP set for a drug administered twice a day may not be appropriate if the same drug is administered three times a day. For example, amoxicillin clavulanate has a set breakpoint according to a defined dosage regimen [11 mg/kg per os (PO) twice daily], ${ }^{21}$ even though an increased dose according to label recommendations (12.5-25 mg/kg PO twice daily) can be used and three doses a day are recommended by international guidelines for treatment of urinary tract infections. ${ }^{45}$ Similarly, for time-dependent drugs such as the $\beta$-lactams, CBPs are heavily influenced by drug formulation. For example, a CBP that is valid for oral tablets may not be valid for the same drug administered by a long-acting intravenous formulation, even if the total dose is the same. To overcome this, several CBPs should be determined for a given substance depending on dose and formulation. However, this approach would be very difficult to manage for diagnostic companies and microbiology laboratories, because commercial systems for AST should be implemented and validated for each CBP.

Currently no CBPs are available for topical antimicrobial therapy, which is often used as a sole treatment in veterinary dermatology, especially for management of otitis externa. The relevance of AST for guiding topical antimicrobial therapy is questionable because CBPs are set for systemic therapy, and the drug concentrations achieved in serum by systemic administration are markedly lower than those obtained by the topical route. Such concentrations may exceed the MICs of skin pathogens greater than 100,000 fold (Table 3). These data suggest that infections 
Table 2. Bacteria for which host- and infection-specific clinical breakpoints exist in veterinary dermatology according to Clinical Laboratory Standards Committee (CLSI). ${ }^{21}$ Drugs for which only human-derived breakpoints are available are highlighted in bold

\begin{tabular}{|c|c|c|}
\hline \multirow[b]{2}{*}{ Antibiotic } & \multicolumn{2}{|c|}{$\begin{array}{l}\text { Animal/bacterial combinations for which clinical breakpoints for systemic treatment of skin } \\
\text { infections exist }\end{array}$} \\
\hline & Dogs & Cats \\
\hline Amoxicillin-clavulanic acid & Escherichia coli, Staphylococcus spp. & $\begin{array}{l}\text { E. coli, Staphylococcus spp., } \\
\text { Streptococcus spp., } \\
\text { Pasteurella spp. }\end{array}$ \\
\hline Ampicillin & $\begin{array}{l}\text { E. coli, Streptococcus canis, Staphylococcus } \\
\text { pseudintermedius }\end{array}$ & None $^{*}$ \\
\hline Cefalothin & $\begin{array}{l}\text { E. coli, Staphylococcus aureus, S. pseudintermedius, } \\
\text { Streptococcus spp. }\end{array}$ & None* \\
\hline Cefazolin & $\begin{array}{l}\text { E. coli, S. aureus, S. pseudintermedius, } \\
\text { Pasteurella multocida, } \\
\text { Streptococcus spp. }\end{array}$ & None* \\
\hline Cefovecin & None & None \\
\hline Cefpodoxime & $\begin{array}{l}\text { E. coli, S. aureus, S. pseudintermedius, } \\
\text { Pasteurella multocida, } \\
\text { Proteus mirabilis, Streptococcus spp. }\end{array}$ & None* \\
\hline Chloramphenicol & None* & None* \\
\hline Clindamycin & Staphylococcus spp., Streptococcus spp. & None* \\
\hline Difloxacine & Enterobacteriaceae, Staphylococcus spp. & None* \\
\hline Doxycycline & Staphylococcus pseudintermedius & None* \\
\hline Enrofloxacin & Enterobacteriaceae, Staphylococcus spp. & None* \\
\hline Gentamicin & None $^{\dagger}$ & None* \\
\hline Marbofloxacin & Enterobacteriaceae, Staphylococcus spp. & None ${ }^{\ddagger}$ \\
\hline Orbifloxacin & Enterobacteriaceae, Staphylococcus spp. & None ${ }^{\star}$ \\
\hline Pradofloxacin & E. coli, S. pseudintermedius & $\begin{array}{l}\text { E. coli, S. pseudintermedius, } \\
\text { Staphylococcus felis, } \\
\text { Staphylococcus aureus, } \\
\text { S. canis, Pasteurella spp. }\end{array}$ \\
\hline Rifampicin & None* & None $^{*}$ \\
\hline Trimethoprim-sulfamethoxazole & None* & None* \\
\hline Tetracycline & Staphylococcus spp. & None* \\
\hline Ticarcillin \pm clavulanic acid & None* & None* \\
\hline
\end{tabular}

* Breakpoints (BP) from human medicine or another animal species are used instead.

$\uparrow$ A generic BP exists for Enterobacteriaceae and Pseudomonas spp. in dogs, but this is not specific to any infection type.

$\ddagger$ A generic BP exists for skin and soft tissue infections in cats, but this is not specific to any bacterial species.

Table 3. Examples of antimicrobial concentrations in veterinary products for topical use and minimum inhibitory concentrations (MICs)

\begin{tabular}{|c|c|c|c|c|c|}
\hline $\begin{array}{l}\text { Active } \\
\text { compound }\end{array}$ & $\begin{array}{l}\text { Examples of } \\
\text { topical products } \\
\text { containing compound }\end{array}$ & $\begin{array}{l}\text { Concentration in } \\
\text { commercial } \\
\text { product }(\mathrm{mg} / \mathrm{L})^{*}\end{array}$ & Reported MIC ranges (mg/L) & $\begin{array}{l}\text { Reported } \\
\text { MIC90 } \\
\text { (mg/L) }\end{array}$ & $\begin{array}{l}\text { References } \\
\text { for MIC } \\
\text { ranges }\end{array}$ \\
\hline Gentamicin & Otomax Vet/EasOtic ${ }^{\circledR}$ & $4,119 / 2,348$ & Pseudomonas aeruginosa: 0.25-16 & 8 & 54 \\
\hline Miconazole & EasOtic ${ }^{\circledR} /$ Surolan ${ }^{\circledR}$ Vet & $13,100 / 19,970$ & Coagulase-positive staphylococci: 1-8 & NA & 55 \\
\hline Polymyxin B & Surolan ${ }^{\circledR}$ Vet & 654 & Coagulase-positive staphylococci: 0.25-64 & NA & 55 \\
\hline Fusidic acid & Canaural $^{\circledR}$ & 4,150 & Coagulase-positive staphylococci: 0.06-1,024 & $0.5-4$ & 56 \\
\hline Framycetin $^{\dagger}$ & Canaural $^{\circledR}$ & 4,300 & $\begin{array}{l}\text { Coagulase-positive staphylococci: } \leq 0.5-64 \\
\text { P. aeruginosa: } 8-1,024\end{array}$ & $\begin{array}{l}\text { NA } \\
128-256\end{array}$ & $\begin{array}{l}55 \\
57\end{array}$ \\
\hline Mupirocin & Muricin $^{\circledR}$ & 20,000 & $\begin{array}{l}\text { Staphylococcus pseudintermedius: } \leq 0.03 \text { to }>1,024 \\
\text { Coagulase-positive staphylococci: } 0.06-16\end{array}$ & $\begin{array}{l}\text { NA } \\
0.125-1\end{array}$ & $\begin{array}{l}58 \\
56\end{array}$ \\
\hline Enrofloxacin & Baytril $^{\circledR}$ Otic & 5,000 & $\begin{array}{l}P . \text { aeruginosa: } 0.015-32 \\
P . \text { aeruginosa: } 0.125 \text { to }>64\end{array}$ & $\begin{array}{l}32 \\
\text { NA }\end{array}$ & $\begin{array}{l}54 \\
59\end{array}$ \\
\hline Florfenicol & Osurnia ${ }^{\circledR}$ & 10,000 & $\begin{array}{l}\text { Escherichia coli: 1->64 } \\
\text { S. pseudintermedius: 0.25-32 } \\
\text { Staphylococcus spp: } 2-32 \\
\text { Streptococcus spp.: 0.5->128 } \\
\text { Proteus spp.: 4-16 } \\
\text { Enterococcus spp.: 1-8 } \\
\text { Pseudomonas spp.: >64 }\end{array}$ & $\begin{array}{l}16 \\
8 \\
8 \\
2->128 \\
8 \\
8 \\
1,024\end{array}$ & 60 \\
\hline
\end{tabular}

NA data not available.

* The concentrations stated for Canaural ${ }^{\circledR}$ and Muricin ${ }^{\circledR}$ represent $\mathrm{mg} / \mathrm{kg}$ instead of $\mathrm{mg} / \mathrm{L}$.

$\uparrow$ Framycetin is a synonym for neomycin B and MIC data are reported here for neomycin.

(C) 2017 The Authors. Veterinary Dermatology published by John Wiley \& Sons Ltd on behalf of the ESVD and ACVD, 28, $146-e 30$. 
caused by strains categorized as resistant by AST can be treated successfully by topical therapy. However, this hypothesis has not been validated clinically or experimentally and needs to be supported by scientific evidence in order to be translated into guidelines for antimicrobial use.

\section{Detection of meticillin resistance in staphylococci}

According to the MRSA expert rule, a $S$. aureus strain found to be meticillin-resistant, as determined by oxacillin, cefoxitin, or detection of mecA or its product PBP2a, should be reported as resistant to all $\beta$-lactams, except those that have been specifically licensed to treat MRSA infections (e.g. ceftaroline and ceftobiprole, which are not licensed for veterinary use). ${ }^{46}$ This rule was established based on clinical and microbiological evidence that MRSA strains display cross-resistance to $\beta$-lactams used in clinical practice for treatment of human staphylococcal infections. This rule has been translated to veterinary medicine without any clinical and/or microbiological evidence that MRSP and meticillin-resistant S. schleiferi (MRSS) display cross-resistance to the $\beta$-lactams used in veterinary dermatology. Various factors suggest that this rule may lead to reporting of false resistance to these $\beta$-lactams in strains expressing low-level meticillin resistance. A considerable proportion of MRSP strains display oxacillin MICs $(0.5-4 \mu \mathrm{g} / \mathrm{mL})$ that are significantly (2-8-fold) lower than the resistance breakpoint for MRSA detection $(R \geq 4 \mu \mathrm{g} / \mathrm{mL}){ }^{47}$ This is why, similarly to CoNS, the resistance breakpoint set for MRSP detection is considerably lower compared to MRSA $(R \geq 0.5 \mu \mathrm{g} / \mathrm{mL}){ }^{21}$ Cefalexin is one of the most active cephalosporins against staphylococci and has been associated with good clinical cure rates (90-100\%) for uncomplicated MRSA skin infections in humans. ${ }^{48,49}$ Studies have demonstrated that cephalosporin resistance in CoNS, which display levels of meticillin resistance comparable to those in MRSP, is dependent on the degree of meticillin resistance expressed by the strain. ${ }^{50}$ Lastly, amoxicillin and ampicillin have been reported to have relatively good affinity for $\mathrm{PBP} 2 \mathrm{a}$, and older in vivo studies claimed anti-MRSA efficacy of high doses of aminopenicillins combined with $\beta$-lactamase inhibitors for treatment of skin and soft tissue infections, and urinary tract infections. ${ }^{51}$

Research to provide evidence to support this expert rule in veterinary medicine is indicated. In the interim, the authors recommend that any oxacillin-resistant staphylococci should be reported as resistant to all $\beta$-lactams licensed for veterinary use. However, if therapy with amoxicillin clavulanate or cefalexin has been initiated and the causative strain has a low MIC of oxacillin, we recommend evaluating the clinical outcome of therapy before changing antimicrobial prescription. As already mentioned, AST has a limited predictive value for infections caused by strains reported as resistant. ${ }^{44}$

Although the cefoxitin disk test is generally recognized as reliable for MRSA detection, a recent study has shown that cefoxitin may not be a good surrogate for MRSP detection by disk diffusion. ${ }^{47}$ In the absence of an internationally recognized cefoxitin breakpoint clearly differentiating mecA-positive from mecA-negative isolates of
S. pseudintermedius, we recommend that laboratories use oxacillin disk or MIC tests for detection of meticillin resistance in this and other staphylococcal species, other than S. aureus.

\section{Result reporting}

Reporting of polymicrobial skin and wound culture results is a challenge, especially when samples derive from contaminated sites. In these cases, the dominant colony type (s) associated with micro-organisms of clinical relevance should be selected or the report should outline that an unspecific mixed growth with limited or no clinical relevance was detected. Samples from ears also tend to be polymicrobial. For these samples, the same principle of reporting the dominant colony type should be used, but additional factors complicate the decision of selection for subculture and AST: (i) relatively few bacterial species (Proteus spp. and Pseudomonas aeruginosa) are obligate pathogens of canine ears, whereas other species also occur in healthy dogs, hence the latter would only be relevant in case of pure or almost pure culture; (ii) Corynebacterium auriscanis should not be selected for AST as it seems clinically irrelevant and there is no CBP for this species. $^{52,53}$ Clinicians should consider the limited value of AST for topical therapy when sampling ear infections and when interpreting results obtained from diagnostic laboratories that indiscriminately report any type of growth.

Various measures such as selective or cascade reporting of AST results can be used by the microbiology laboratory to guide rational choice of antimicrobials. This approach is used extensively in human hospitals to encourage use of first-line drugs. The practice of not reporting the results for selected agents is regarded as selective reporting. For example, AST data should not be reported for critically important drugs that are not licensed for veterinary use (e.g. imipenem, vancomycin and linezolid), even if these drugs are included in the antimicrobial panel as last-resort agents for surveillance purposes. Cascade reporting is the practice of reporting the AST result for only one drug that tests susceptible within a certain class (e.g. gentamicin within the aminoglycosides) to reduce the use of more expensive and/or broader spectrum drugs of the same class (e.g. amikacin). In the absence of guidelines for selective or cascade reporting, decisions should be made in consultation with an infectious disease specialist. Linking the clinic to the laboratory information management system to enable data exchange and implementation of antimicrobial stewardship programmes would be optimal. ${ }^{7}$ A variety of software programmes are available on the market for effective management of veterinary practices but they are not designed to interact with the laboratory or are difficult to implement. It is desirable for manufacturing companies to improve veterinary practice management software in order to facilitate antimicrobial stewardship.

\section{Conclusions}

The microbiology laboratory should play an important role in the diagnosis of infectious diseases by providing key support to various steps of the diagnostic process, from specimen collection and transportation to 
interpretation of AST results. The laboratory's role and responsibilities should extend beyond correct specimen testing and reporting of results, and include guidance in both the pre- and postanalytical phases of the diagnostic process. Furthermore, a good microbiology service is essential for implementation of antimicrobial stewardship programmes in veterinary practice.

The advent of MALDI-TOF MS in clinical microbiology has significantly reduced the time required for bacterial ID and facilitated ID of veterinary pathogens that previously could not be identified. The concomitant developments in genome sequencing technologies are improving our understanding of the taxonomy, ecology and population structure of key pathogens in veterinary dermatology such as S. pseudintermedius and S. schleiferi. Despite these technological advances, veterinary diagnostic microbiology is still based predominantly on traditional culture methods, and the turnaround time for AST has essentially remained unchanged for many years. Methods for AST are not yet harmonized and clinical breakpoints for important drug-pathogen combinations are either missing or inadequate. Small veterinary microbiology laboratories, including in-clinic laboratories, often neither have the infrastructure nor the expertise required to run up-to-date clinical microbiology, and adequate postgraduate training in veterinary clinical microbiology is not available in most countries.

ESGVM recommends that diagnostic microbiology laboratories are selected by veterinary practitioners taking into consideration the following factors:

- Guidance for optimal specimen management (i.e. selection, collection, storage and transportation of clinical specimens).

- State-of-the-art methods for ID (MALDI-TOF- MS) and AST (MIC determination by broth micro-dilution).

- Implementation of transparent and ongoing quality assurance measures, preferably by accredited laboratories

- Availability of skilled microbiologists for case-based expert advice and data interpretation.

Other factors include the availability of a courier system for overnight delivery of specimens to the laboratory, and access to data for passive epidemiological surveillance and implementation of antimicrobial stewardship programmes at the clinic level. Certification of veterinary microbiologists at a national or, preferably, international level should be a prerequisite. National accreditation, such as according to ISO standards, should be obtained to ensure minimum quality and safety standards.

ESGVM supports the development of PoC tests that could rationalize antimicrobial use in veterinary practice, provided that (i) the performance of the test has been evaluated scientifically, (ii) clinical staff are adequately trained to interpret the results and (iii) clinics meet the minimal requirements for handling microbiological specimens (biosafety level 1). There is concern about direct AST replacing conventional AST due to the potential for error and the subsequent selection of a drug that is not effective.

ESGVM has a mission to set standards for veterinary clinical microbiology, including methods and training, and the promotion of antimicrobial stewardship and constructive interaction between microbiologists and clinicians. The group promotes diagnostic microbiology in veterinary practice by standardizing procedures and by educating veterinarians about the key role played by microbiology laboratories in antimicrobial stewardship and patient care. ESGVM strongly supports (i) global harmonization of methods and setting of infection-, animal- and bacterialspecific CBPs for AST of veterinary pathogens; (ii) postgraduate education and board certification of specialists in veterinary clinical microbiology and antimicrobial stewardship; (iii) official licensing of veterinary diagnostic microbiology laboratories and quality assurance to guarantee the minimum quality and biosafety standards required to perform veterinary microbiology; and (iv) development of new diagnostic tests providing veterinarians with rapid and reliable results at reasonable cost.

ESGVM has supported the creation of VetCAST and established an ESCMID postgraduate educational course on Antimicrobial Stewardship in Veterinary Medicine (https://www.escmid.org/index.php?id=1755).

\section{Acknowledgements}

None.

\section{References}

1. De Briyne N, Atkinson J, Pokludová L et al. Factors influencing antibiotic prescribing habits and use of sensitivity testing amongst veterinarians in Europe. Vet Rec 2013; 173: 475.

2. Guardabassi L, Prescott JF. Antimicrobial stewardship in small animal veterinary practice: from theory to practice. Vet Clin North Am Small Anim Pract 2015; 45: 361-376.

3. European Medicines Agency (EMA), Committee for Medicial Products for Veterinary Use (CVMP), Antimicrobials Working Party (AWP). Reflection paper on the risk of antimicrobial resistance transfer from companion animals. EMA/CVMP/AWP/ 401740/2013. 2015. Available at: http://www.ema.europa.eu/d ocs/en_GB/document_library/Scientific_guideline/2015/01/WC5 00181642.pdf. Accessed Nov 17, 2016

4. EU Commission. Guidelines for the prudent use of antimicrobials in veterinary medicine. Commission Note (2015/C 299/04). Official Journal of the European Union. 2015; 7-26. Available at: http://ec.europa.eu/health/antimicrobial_resistance/docs/2015_ prudent_use_guidelines_en.pdf. Accessed Nov 17, 2016

5. World Organization of Animal Health (OIE). Laboratory methodologies for bacterial antimicrobial susceptibility testing. In: Manual of Diagnostic Tests and Vaccines for Terrestrial Animals. 2015. Available at: http://www.oie.int/international-standard-se tting/terrestrial-manual/. Accessed Nov 17, 2016

6. American Veterinary Medical Association (AVMA). Judicious therapeutic use of antimicrobials. Available at: https://www. avma.org/KB/Policies/Pages/Judicious-Therapeutic-Use-of-Anti microbials.aspx. Accessed Nov 17, 2016

7. MacDougall C, Polk RE. Antimicrobial stewardship programs in health care systems. Clin Microbiol Rev 2005; 18: 638-656.

8. International Organization for Standardization (ISO) and the International Electrotechnical Commission (IEC). General requirements for the competence of testing and calibration laboratories (ISO/IEC 17025:2005). Available at http://www.iso.org/iso/cat alogue_detail?csnumber=39883. Accessed Nov 17, 2016.

9. International Organization for Standardization (ISO ). Clinical laboratory testing and in vitro diagnostic test systems. Susceptibility testing of infectious agents and evaluation of performance of antimicrobial susceptibility test devices. Part 1: reference 
method for testing the in vitro activity of antimicrobial agents against rapidly growing aerobic bacteria involved in infectious diseases (ISO 20776-1: 2006). 2006. Available at: http://www.iso.org/iso/catalogue_detail.htm?csnumber $=41630$. Accessed Nov 17, 2016.

10. Jorgensen JH, Pfaller MA, Carroll KC et al. Manual of Clinical Microbiology. 11th edition. American Society for Microbiology, 2015.

11. Cornaglia G, Courcol R, Herrmann J-L et al. European Manual of Clinical Microbiology. European Society of Clinical Microbiology and Societe Francaise de Microbiologie, 2012

12. Tran A, Alby K, Kerr A et al. Cost savings realized by implementation of routine microbiological identification by matrix-assisted laser desorption ionization-time of flight mass spectrometry. J Clin Microbio/ 2015; 53: 2,473-2,479.

13. Bilecen K, Yaman G, Ciftci U et al. Performances and reliability of Bruker Microflex LT and VITEK MS MALDI-TOF mass spectrometry systems for the identification of clinical microorganisms. Biomed Res Int 2015; 2015: 516410.

14. Murugaiyan J, Walther B, Stamm I et al. Species differentiation within the Staphylococcus intermedius group using a refined MALDI-TOF MS database. Clin Microbiol Infect 2014; 20: 1,0071,015 .

15. La Scola B. Intact cell MALDI-TOF mass spectrometry-based approaches for the diagnosis of bloodstream infections. Expert Rev Mol Diagn 2011; 11: 287-298.

16. Long SW, Williams $D$, Valson $C$ et al. A genomic day in the life of a clinical microbiology laboratory. J Clin Microbiol 2013; 51: 1,272-1,277

17. Dunne WM Jr, Westblade LF, Ford B. Next-generation and whole-genome sequencing in the diagnostic clinical microbiology laboratory. Eur J Clin Microbiol Infect Dis 2012; 31: 1,719 1,726 .

18. Larsen MV, Cosentino S, Rasmussen S et al. Multilocus sequence typing of total-genome-sequenced bacteria. J Clin Microbiol 2012; 50: 1,355-1,361.

19. Zankari E, Hasman $H$, Cosentino $S$ et al. Identification of acquired antimicrobial resistance genes. J Antimicrob Chemother 2012; 67: 2,640-2,644

20. Hasman H, Saputra D, Sicheritz-Ponten T et al. Rapid wholegenome sequencing for detection and characterization of microorganisms directly from clinical samples. J Clin Microbio 2014; 52: 139-146.

21. Clinical and Laboratory Standards Institute. Performance standards for antimicrobial disk and dilution susceptibility tests for bacteria isolated from animals: approved standards - fourth edition. CLSI document VET01-A4. Wayne, PA: CLSI; 2013.

22. Huletsky A, Giroux $R$, Rossbach $V$ et al. New real-time PCR assay for rapid detection of methicillin-resistant Staphylococcus aureus directly from specimens containing a mixture of staphylococci. J Clin Microbiol 2004; 42: 1,875-1,884

23. Oviaño M, Fernández $B$, Fernández $A$ et al. Rapid detection of enterobacteriaceae producing extended spectrum beta-lactamases directly from positive blood cultures by matrix-assisted laser desorption ionization-time of flight mass spectrometry. Clin Microbiol Infect 2014; 20: 1,146-1,157

24. Faria-Ramos I, Espinar MJ, Rocha R et al. A novel flow cytometric assay for rapid detection of extended-spectrum beta-lactamases. Clin Microbiol Infect 2013; 19: E8-E15.

25. Drancourt M, Michel-Lepage A, Boyer S et al. The point-of-care laboratory in clinical microbiology. Clin Microbiol Rev 2016; 29 : 429-447.

26. Jacob ME, Crowell MD, Fauls MB et al. Diagnostic accuracy of a rapid immunoassay for point of-care detection of urinary tract infection in dogs. Am J Vet Res 2016; 77: 162-166.

27. Coorevits L, Boelens J, Claeys G. Direct susceptibility testing by disk diffusion on clinical samples: a rapid and accurate tool for antibiotic stewardship. Eur J Clin Microbiol Infect Dis 2015; 34: $1,207-1,212$

28. Guardabassi L, Hedberg S, Jessen LR et al. Optimization and evaluation of Flexicult $^{\circledR}$ Vet for detection, identification and antimicrobial susceptibility testing of bacterial uropathogens in small animal veterinary practice. Acta Vet Scand 2015; 57: 72.

29. Baron EJ, Miller JM, Weinstein MP et al. A guide to utilization of the microbiology laboratory for diagnosis of infectious diseases: 2013 recommendations by the Infectious Diseases Society of America (IDSA) and the American Society for Microbiology (ASM). Clin Infect Dis 2013; 57: e22-e121.

30. Hillier A, Lloyd DH, Weese JS et al. Guidelines for the diagnosis and antimicrobial therapy of canine superficial bacterial folliculitis (Antimicrobial Guidelines Working Group of the International Society for Companion Animal Infectious Diseases). Vet Dermatol 2014; 25: 163-175, e42-3.

31. Bowler PG, Duerden BI, Armstrong DG. Wound microbiology and associated approaches to wound management. Clin Microbiol Rev 2001; 14: 244-269.

32. Pinchbeck LR, Cole LK, Hiller A et al. Pulsed-field gel electrophoresis patterns and antimicrobial susceptibility phenotypes for coagulase-positive staphylococcal isolates from pustules and carriage sites in dogs with superficial bacterial folliculitis. Am J Vet Res 2007; 68: 535-542.

33. Wegener HC, Pedersen K. Variations in antibiograms and plasmid profiles among multiple isolates of Staphylococcus intermedius from pyoderma in dogs. Acta Vet Scand 1992; 33: 391-394.

34. Paul NC, Bärgman SC, Moodley A et al. Staphylococcus pseudintermedius colonization patterns and strain diversity in healthy dogs: a cross-sectional and longitudinal study. Vet Microbiol 2012; 160: 420-427.

35. Hajek V. Staphylococcus intermedius, a new species isolated from animals. Int J Syst Bacteriol 1976; 26: 401-408.

36. Bannoehr J, Ben Zakour NL, Waller AS et al. Population genetic structure of the Staphylococcus intermedius group: insights into agr diversification and the emergence of methicillin-resistant strains. J Bacteriol 2007; 189: 8,685-8,692.

37. Bannoehr J, Guardabassi L. Staphylococcus pseudintermedius in the dog: taxonomy, diagnostics, ecology, epidemiology and pathogenicity. Vet Dermato/ 2012; 23: 253-266, e51-e2.

38. Bagcigil FA, Moodley A, Baptiste KE et al. Occurrence, species distribution, antimicrobial resistance and clonality of methicillinand erythromycin-resistant staphylococci in the nasal cavity of domestic animals. Vet Microbio/ 2007; 15: 307-315.

39. Cain CL, Morris DO, O'Shea K et al. Genotypic relatedness and phenotypic characterization of Staphylococcus schleiferi subspecies in clinical samples from dogs. Am J Vet Res 2011; 72: 96-102.

40. May ER, Hnilica KA, Frank LA et al. Isolation of Staphylococcus schleiferi from healthy dogs and dogs with otitis, pyoderma, or both. J Am Vet Med Assoc 2005; 227: 928-931.

41. Loonen AJ, Jansz AR, Bergland JN et al. Comparative study using phenotypic, genotypic, and proteomics methods for identification of coagulase-negative staphylococci. J Clin Microbiol 2012; 50: 1,437-1,439.

42. Turnidge J, Paterson DL. Setting and revising antibacterial susceptibility breakpoints. Clin Microbiol Rev 2007; 20: 391-408.

43. Murray PR. Antimicrobial susceptibility tests: testing methods and interpretive problems. Adv Exp Med Biol 1994; 349: 1525.

44. Doern GV, Brecher SM. The clinical predictive value lor lack thereof) of the results of in vitro antimicrobial susceptibility tests. J Clin Microbiol 2011; 49(Suppl 9): S11-S14.

45. Weese JS, Blondeau JM, Boothe D et al. Antimicrobial use guidelines for treatment of urinary tract disease in dogs and cats: antimicrobial guidelines working group of the international society for companion animal infectious diseases. Vet Med Int 2011; 2011: 263768

46. Leclercq R, Cantón R, Brown DF et al. EUCAST expert rules in antimicrobial susceptibility testing. Clin Microbiol Infect 2013; 19: 141-160.

47. Wu MT, Burnham CA, Westblade LF et al. Evaluation of oxacillin and cefoxitin disk and MIC breakpoints for prediction of methicillin resistance in human and veterinary isolates of Staphylococcus intermedius Group. J Clin Microbio/ 2016; 54: 535-542. 
48. Giordano PA, Elston D, Akinlade BK et al. Cefdinir vs. cephalexin for mild to moderate uncomplicated skin and skin structure infections in adolescents and adults. Curr Med Res Opin 2006; 22: 2,419-2,428.

49. Chen AE, Carroll KC, Diener-West $M$ et al. Randomized controlled trial of cephalexin versus clindamycin for uncomplicated pediatric skin infections. Pediatrics 2011; 127: e573-e580.

50. Menzies RE, Cornere BM, MacCulloch D. Cephalosporin susceptibility of methicillin-resistant, coagulase-negative staphylococci. Antimicrob Agents Chemother 1987; 31: 42-45.

51. Guignard B, Entenza JM, Moreillon P. Beta-lactams against methicillin-resistant Staphylococcus aureus. Curr Opin Pharmacol 2005; 5: 479-489.

52. Aalbæk B, Bemis DA, Schjærff M et al. Coryneform bacteria associated with canine otitis externa. Vet Microbiol 2010; 145: 292-298.

53. Henneveld K, Rosychuk RA, Olea-Popelka FJ et al. Corynebacterium spp. in dogs and cats with otitis externa and/or media: a retrospective study. J Am Anim Hosp Assoc 2012; 48: 320-326.

54. Rubin J, Walker RD, Blickenstaff $K$ et al. Antimicrobial resistance and genetic characterization of fluoroquinolone resistance of Pseudomonas aeruginosa isolated from canine infections. Vet Microbio/ 2008; 131: 164-172.

55. Boyen F, Verstappen KM, De Bock M et al. In vitro antimicrobial activity of miconazole and polymyxin $B$ against canine meticillin- resistant Staphylococcus aureus and meticillin-resistant Staphylococcus pseudintermedius isolates. Vet Dermatol 2012; 23: 381-385, e70.

56. Loeffler A, Baines SJ, Toleman MS et al. In vitro activity of fusidic acid and mupirocin against coagulase-positive staphylococci from pets. J Antimicrob Chemother 2008; 62: 1,301-1,304.

57. Pye CC, Yu AA, Weese JS. Evaluation of biofilm production by Pseudomonas aeruginosa from canine ears and the impact of biofilm on antimicrobial susceptibility in vitro. Vet Dermatol 2013; 24: 446-449, e98-9.

58. Matanovic K, Pérez-Roth E, Pintarić S et al. Molecular characterization of high-level mupirocin resistance in Staphylococcus pseudintermedius. J Clin Microbiol 2013; 51: 1,0051,007 .

59. Trott DJ, Moss SM, See AM et al. Evaluation of disc diffusion and MIC testing for determining susceptibility of Pseudomonas aeruginosa isolates to topical enrofloxacin/silver sulfadiazine. Aust Vet J 2007; 85: 464-466.

60. European Medicines Agency (EMA), Committee for Medicial Products for Veterinary Use (CVMP). CVMP assessment report for granting of marketing authorisation for OSURNIA (EMEAN/ C/003753/0000) EMA/344014/2014. Available at: http://www.e ma.europa.eu/docs/en_GB/document_library/EPAR_-_Public_ assessment_report/veterinary/003753/WC500171494.pdf Accessed Nov 17, 2016

\section{Résumé}

Contexte - Le laboratoire de microbiologie peut être considéré comme un fournisseur de service plus que comme un partenaire à part entière du parcours de soins.

Objectifs - Le but de cette revue est de discuter des défis actuels de fournir un service de microbiologie vétérinaire dans les règles de l'art comprenant l'identification (ID) et les tests de sensibilité antimicrobienne (AST) des pathogènes clés en dermatologie vétérinaire.

Méthodes - L'ESGVM (Study Group for Veterinary Microbiology) de l'ESCMID (European Society of Clinical Microbiology and Infectious Diseases) a identifié les omissions régulières scientifiques, technologiques, pédagogiques influant sur la valeur prédictive de l'AST et la qualité de service offerte par les laboratoires de microbiologie.

Résultats - Le développement de la spectrométrie de masse a significativement réduit le temps nécessaire à l'identification des pathogènes clés tels que Staphylococcus pseudintermedius. Cependant, le délai de production pour des méthodes d'AST validées reste inchangé depuis plusieurs années. Au-delà des contraintes scientifiques et technologiques, les méthodes d'AST ne sont pas harmonisées et les points de rupture clinique pour certains antimicrobiens sont soit manquant soit inadaptés. Les petits laboratoires, comprenant les laboratoires internes aux cliniques ne sont généralement pas équipé de façon adéquat pour réaliser des tests diagnostiques microbiologiques cliniques actualisés et adaptés.

Conclusions et importance clinique - L'ESGVM recommande l'utilisation de laboratoires utilisant la spectrométrie de masse pour l'identification et la microdilution pour l'AST et offrant une assistance par des experts microbiologistes sur les données pré et post analytiques. Les données générales standards pour la microbiologie vétérinaire clinique promouvant l'administration antimicrobienne, et le développement de méthodes de diagnostic rapides, validées et nouvelles, en particulier pour l'AST font partie des missions de I'ESGVM.

\section{Resumen}

Introducción - El laboratorio de microbiología puede ser percibido como un proveedor de servicios en lugar de ser una parte integral del equipo de salud.

Objetivos - El objetivo de esta revisión es discutir los retos actuales de proporcionar un servicio de microbiología veterinaria de diagnóstico de vanguardia, incluyendo la identificación (ID) y la prueba de susceptibilidad antimicrobiana (AST) de patógenos claves en dermatología veterinaria.

Métodos - El Grupo de Estudio de Microbiología Veterinaria (ESGVM) de la Sociedad Europea de Microbiología Clínica y Enfermedades Infecciosas (ESCMID) identificó omisiones científicas, tecnológicas, educativas y regulatorias que afectan al valor predictivo de AST y a la calidad del servicio ofrecido por los laboratorios de microbiología.

Resultados - La llegada de la espectrometría de masas ha reducido significativamente el tiempo requerido para la identificación de patógenos clave como Staphylococcus pseudintermedius. Sin embargo, el tiempo de respuesta para los métodos AST validados se ha mantenido sin cambios durante muchos años. Más allá de las limitaciones científicas y tecnológicas, los métodos AST no están armonizados y los puntos de corte clínicos para algunos fármacos antimicrobianos no están determinados o son inadecuados. Los pequeños 
laboratorios, incluidos los laboratorios dentro de las clínicas, generalmente no están adecuadamente equipados para realizar pruebas de diagnóstico microbiológico clínico actualizadas.

Conclusiones e importancia clínica - ESGVM recomienda el uso de laboratorios que emplean espectrometría de masas para ID y micro-dilución de caldo de cultivo para AST, y que ofrecen asistencia de microbiólogos expertos en cuestiones pre- y post-analíticas. Entre las misiones del ESGVM figuran el establecimiento de normas generales para la microbiología clínica veterinaria, la promoción de la administración antimicrobiana y el desarrollo de métodos de diagnóstico nuevos, validados y rápidos, especialmente para la AST.

\section{Zusammenfassung}

Hintergrund - Das Mikrobiologielabor ist eher als Dienstleister und nicht als ein integraler Bestandteil des Gesundheitsteams zu betrachten.

Ziele - Das Ziel dieser Review ist eine Diskussion über die derzeitigen Herausforderungen ein State-of-theArt diagnostisches veterinärmikrobiologisches Service zu bieten, welches die Identifizierung (ID) und die antimikrobiellen Empfindlichkeitstests (AST) der Schlüsselpathogene der Veterinärdermatologie inkludiert.

Methoden - Die Forschungsgruppe für Veterinärmikrobiologie (ESGVM) der European Society für klinische Mikrobiologie und Infektiöse Erkrankungen (ESCMID) identifizierte wissenschaftliche, technologische, erzieherische und angeordnete Weglassungen, welche den Vorhersagewert für AST und die Qualität der geleisteten Dienste durch die Mikrobiologielaboratorien beeinflusste.

Ergebnisse - Das Erscheinen der Massenspektrometrie hat die Zeit, die für die ID der Schlüsselpathogene wie Staphylococcus pseudintermedius nötig ist, signifikant reduziert. Nichtsdestotrotz bleibt die Umlaufzeit für validierte AST Methoden seit vielen Jahren unverändert. Neben wissenschaftlichen und technologischen Grenzen sind die AST Methoden nicht harmonisiert und die klinischen Messpunkte für einige antimikrobielle Wirkstoffe fehlen entweder oder sie sind nicht adäquat. Kleine Laboratorien, zu denen auch die Laboratorien in den Kliniken gehören, sind normalerweise nicht ausreichend ausgerüstet, um klinische mikrobiologische diagnostische Tests auf dem neuesten Stand durchzuführen.

Schlussfolgerungen und klinische Bedeutung - Die ESGVM empfiehlt die Verwendung von Laboratorien, die die Massenspektrometrie zur ID und ein Mikrobouillon-Dilutionsverfahren für AST einsetzen und Unterstützung von Mikrobiologieexperten bei Problemen vor sowie nach der Analyse anbieten. Das Etablieren von Allgemeinstandards für die klinische Veterinärmikrobiologie, antimikrobiologische Verantwortung zu fördern und die Entwicklung von neuen, validierten und raschen diagnostischen Methoden, vor allem für AST, sind unter anderem Ziele von ESGVM.

\section{要約}

背景 - 微生物検査機関は医療チームの不可欠な一員としてよりも、サービス提供機関として認識されて いる。

目的 - 本総論では、獣医皮膚科領域で重要な病原体の細菌同定(ID)および抗菌剤感受性試験(AST)などを 含めた最新鋭の獣医微生物学診断サービスを提供するための現在の取り組みを紹介する。

方法 - ヨーロッパ臨床微生物感染症学会(ESCMID)の獣医細菌学研究会(ESGVM)によって、予想される ASTの結果や微生物検查機関の提供サービスの質に影響を与えると考えられる科学的、技術的、教育的 および制御的遺漏が検証された結果質量分析法の出現により、Staphylococcus pseudintermediusなどの重要 な病原体のIDにかかる時間が大幅に軽減された。しかしながら、妥当なAST法に要する時間は長年変 わっていない。科学的およ技術的制約以外に、AST法は統一されておらず、いくつかの抗菌薬に対する 臨床的なブレイクポイントは存在しない、あるいは不適切である。院内検査機関を含めた小規模な検査 機関では、多くの場合、最新の臨床微生物診断検査を実施するための適切な設備を持っていない。

結論および臨床的な重要性 - ESGVMは、IDに質量分析法を、ASTにブロス微量希釈法を使用し、また、 解析前後の問題に対して専門の微生物学者の補佐を提供している検查機関を利用することを推奨する。 獣医臨床微生物学の準則の設定、抗菌剂管理責任の推進、そして、特にASTに対する妥当かつ迅速な新 たな診断法の確立がESGVMの役目である。

\section{摘要}

背景 - 微生物学实验室不是医疗团队的成员,但可以作为技术的提供者。

目的 - 本文在现有技术条件下, 讨论兽医微生物学提供诊断时面临的挑战, 其中包括动物皮肤病学的关键病 原的菌种鉴定(ID)和抗菌药物敏感性试验(AST)。

方法 一 欧洲临床微生物与传染病学会(ESCMID)的兽医微生物研究团队(ESGVM), 确认微生物实验室的科学 性、技术性、教育和监管疏漏,可能对AST预测价值和服务质量的影响

结果 一 质谱法的出现大大缩短了关键病原的ID需要时间, 例如假中间型葡萄球菌。但是, AST方法的大致时 间仍维持多年未变。脱离了科学和技术的制约, AST法不一致, 并且一些抗菌药物的临床断点, 不是错误的就 是不合理的。小型实验室,包括诊所内的化验室,通常配置无法跟进最新的临床微生物诊断技术。

结论和临床意义 - ESGVM推荐实验室使用质谱法测ID, 对AST用肉汤微稀释法, 并由微生物学专家提供帮助 分析前后问题。建立兽医临床微生物学的总标准, 改进抗菌药的管理方式, 尤其对于AST发展新的、有效和快 速的诊断方法,这些都涵盖在ESGVM的工作范畴中。 


\section{Resumo}

Contexto - O laboratório de microbiologia pode ser tido como um prestador de serviços ao invés de uma parte integral da área da saúde.

Objetivos - O objetivo desta revisão é discutir os desafios atuais de fornecer um serviço de diagnóstico em microbiologia veterinária de alto padrão de qualidade, incluindo testes de identificação (ID) e susceptibilidade a antimicrobianos (SAM) de patógenos relevantes em dermatologia veterinária.

Métodos - O Grupo de Estudos em Microbiologia Veterinária (GEMV) da Sociedade Europeia de Microbiologia Clínica e Doenças Infecciosas (SEMCDI) identificou omissões científicas, tecnológicas, educacionais e regulatórias que impactam no valor preditivo de SAM e na qualidade dos serviços oferecidos pelos laboratórios de microbiologia.

Resultados - O advento da espectrometria de massa reduziu significativamente o tempo requerido para ID de patógenos importantes como Staphylococcus pseudintermedius. Entretanto, o tempo de processamento necessário para SAM tem se mantido o sem alterações há anos. Além de limitações tecnológicas e científicas, métodos de SAM não são harmonizados e os intervalos de suscetibilidade e resistência para determinados antibióticos são inadequados ou inexistentes. Laboratórios pequenos, incluindo os internos de clínicas, são geralmente inadequadamente equipados para processar testes microbiológicos atualizados.

Conclusões e importância clínica - SEMCDI recomenda o uso de laboratórios que utilizam espectrometria de massa para ID e microdiluição em caldo para SAM, e ofereçam assistência de microbiologistas para problemas pré e pós-analíticos. Desenvolver padronização para microbiologia veterinária clínica, promover regulação e melhorias no uso de antimicrobianos e o desenvolvimento de novos métodos de diagnóstico rápidos e validados, especialmente para SAM, estão entre as funções de SEMCDI. 